\title{
KERJASAMA ASING DENGAN PEMERINTAH INDONESIA DALAM MENGATASI PENINGKATAN PERNIKAHAN ANAK SELAMA PANDEMI COVID-19
}

\author{
Farahdiba Rahma Bachtiar ${ }^{1}$, Nirwana ${ }^{2}$, Waode Surya Darmadali ${ }^{3}$ \\ 1,2,3UIN Alauddin Makassar \\ E-mail: farahdiba.rahma@uin-alauddin.ac.id, nirwana.nirwana@uin-alauddin.ac.id, \\ waode.surya@uin-alauddin.ac.id
}

\begin{abstract}
Abstrak:
Perkawinan anak di Indonesia termasuk cukup tinggi yang naik dari 2019 yang hanya 23.700 menjadi 34.000 pengajuan (Katadata, 2021). Kondisi ini memburuk di masa pandemi Covid 19. Berdasarkan hal tersebut, maka tulisan ini bertujuan untuk menjawab pertanyaan mengenai bagaimana peran negara dan non- negara dalam mengatasi perkawinan anak di Indonesia terutama selama Pandemi Covid-19 dan bagaimana mereka mengatasi tantangan yang terjadi di lapangan dalam upaya advokasi tersebut. Hal ini bertujuan bukan hanya memperkaya kajian terkait dengan persoalan perkawinan anak namun juga menjadi masukan bagi berbagai pihak terkait untuk mengevaluasi skema kerjasama selama ini. Metode penelitian yang digunakan dalam penelitian ini adalah penelitian analisis kualitatif berdasarkan metode tringulasi sumber data dengan melakukan perbandingan studi pustaka/dokumentasi dari pihak pemerintah Indonesia, dari pihak asing dan lembaga masyarakat di Indonesia. Penelitian ini sendiri menemukan bahwa aktor asing sangat berperan besar dalam bukan hanya mengatasi masalah perkawinan anak tapi juga dalam mencegahnya baik melalui pemberian bantuan teknis, pelatihan dan upaya advokasi berupa kerjasama lembaga internasional dan universitas serta lembaga pendidikan keagaamaan dan dukungan terhadap organisasi kemasyarakatan.
\end{abstract}

Kata Kunci: Kerjasama asing, Pernikahan anak, Pandemi Covid 19

\begin{abstract}
The number of child marriages in Indonesia had risen significantly since 2019 from 23,700 to 34,000 (Katadata, 2021). The condition worsened during the Covid19 pandemic. Based on this fact, this article was aimed to answer issues about the role of government and nongovernmental actors in overcoming child marriage in Indonesia especially during the COVID-19 pandemic and how they addressed local advocacy issues. It focused on not only to enrich research related to child marriage, but also to help the various involved parties in evaluating current collaboration plans. The research method used in this study was a qualitative and analytical study based on the method of triangulating data sources by comparing literature/documentary studies of the Indonesian government, foreign political parties, and Indonesian civil society organizations. The results pointed out that foreign actors played an important role not only in overcoming the problem of child marriage, but also in preventing it through the provision of technical assistance, training, and advocacy efforts in the form of collaborations with international organizations and universities with the support of religious institutions and public institutions.
\end{abstract}

Key Words: Child Marriage, Covid-19 Pandemic, Foreign Collaboration 


\section{PENDAHULUAN}

Pandemi Covid 19 telah berdampak luas bukan hanya kepada stabilitas negara namun juga pada stabilitas internasional secara luas. Pembatasan wilayah dilakukan oleh berbagai negara di dunia baik antar wilayah di dalam negerinya maupun perbatasan dengan negara lain yang dikenal sebagai lockdown (Detikcom, 2021). Baik negara maju seperti Amerika Serikat, Inggris,Jepang,Australia dan negara-negara Uni Eropa yang memiliki sistem kesehatan yang unggul maupun negara-negara berkembang dan miskin seperti China di mana Virus berasal, Indonesia dan Bangladesh harus mengambil langkah untuk menutup batas wilayahnya (close border) (Mary A. Shiraef, 2021). Connor (2020) dari Pew Research Center bahkan mengklaim bahwa 91 \% masyakarat dunia hidup dalam negara yang melakukan penutupan wilayah.

Penutupan wilayah tersebut merupakan implikasi dari kerugiaan yang disebabkan oleh Pandemi Covid 19. Menurut WHO (2021), pandemi Covid 19 telah membunuh hampir lima juta orang di seluruh dunia dan 143 ribu di Indonesia. Kerugian ekonomi akibat pandemi juga sangat besar menyebabkan resesi global. Penurunan aktivitas ekonomi secara global turun drastis(Bappenas, 2020c). Kerugian ekonomi ini juga tercermin dari menurunnya GDP hampir seluruh negara termasuk Indonesia (Kompas, 2021). Akibat turunnya aktivitas ekonomi dunia menyebabkan pula turunnya produktivitas ekonomi terutama sektor seperti pariwisata dan transportasi, perdagangan dan konstruksi bahkan manufaktur(Bappenas, 2020c).

Pandemi Covid juga berdampak baik secara langsung maupun tidak langsung terhadap aspek sosial. Secara langsung, pandemi Covid 19 menyebabkan pergeseran pola interaksi masyarakat. Secara tidak langsung, pandemi Covid 19 menyebabkan berbagai masalah sosial terutama kemiskinan dan kesenjangan yang makin meluas. Menurut data dari jumlah orang miskin di Indonesia saat ini mencapai 28 juta jiwa(BBC Indonesia, 2021). Mulai dari tingginya angka pengangguran mencapai 17,66 \% (Mutia, 2021) dan termasuk perkawinan anak. Perkawinan anak di dunia mengalami kenaikan dalam dua tahun terakhir data perkawinan anak di Afrika 2020-2021 mencapai 9.600 kasus dan di Asia Selatan 
mencapai 2.000 kasus (Save The Children, 2021). Di Indonesia sendiri perkawinan anak termasuk cukup tinggi. Kondisi ini memburuk di masa pandemi Covid 19. Berdasarkan data dari Katadata (2021)dispensasi perkawinan pada 2020 naik dari 2019 yang hanya 23.700 menjadi 34.000 pengajuan. Pengajuan ini didominasi oleh keinginan untuk menikah di bawah umur(Katadata, 2021).

Persoalan pernikahan anak selama Pandemi Covid 19 menjadi makin parah dan bukan hanya menjadi perhatian pemerintah Indonesia. Pemerintah Indonesia sendiri tidak akan mampu menyelesaikan persoalan perkawinan anak sendiri. Kerjasama internasional dalam mengatasi perkawinan anak menjadi penting dalam dua segi. Pertama, isu perkawinan anak merupakan isu bersama dalam Sustainable Development Goals (SDGs) yang merupakan target bersama pemerintah Indonesia bersama Perserikatan Bangsa-Bangsa (PBB). Kedua, Pandemi Covid 19 merupakan masalah baru yang berdampak terhadap semua negara dan aspek kehidupan sehingga tentu saja membutuhkan kolaborasi semua pihak dan semua sektor. Sehingga, kerjasama merupakan langkah kunci dari upaya mengatasi masalah tersebut.

Berdasarkan hal tersebut, maka tulisan ini berusaha memahami bagaimana isu perkawinan anak kemudian di Indonesia diatasi secara bersama dengan pihak asing melalui kerjasama dan kolaborasi baik oleh aktor atau lembaga negara maupun oleh non-negara. Dengan kata lain, tulisan ini berusaha untuk menjawab pertanyaan mengenai bagaimana peran negara dan non- negara dalam mengatasi perkawinan anak di Indonesia terutama selama Pandemi Covid-19 dan bagaimana mereka mengatasi tantangan yang terjadi di lapangan dalam upaya advokasi tersebut. Hal ini bertujuan bukan hanya memperkaya kajian terkait dengan persoalan perkawinan anak namun juga menjadi masukan bagi berbagai pihak terkait untuk mengevaluasi skema kerjasama selama ini.

\section{TINJAUAN PUSTAKA}

Penelitian terkait kerjasama asing dan Indonesia dalam mengatasi perkawinan anak belum banyak dilakukan di Indonesia dan cenderung menggunakan pendekatan agama, hukum ataupun sosiologi. Begitupula dengan 
penelitian terkait dengan dampak pandemi Covid 19 terhadap perkawinan anak yang masih terbatas. Oleh karena itu, penelitian ini menggunakan perspektif kerjasama internasional dalam memahami bagaimana kemitraan internasional baik antar negara dan negara dan negara dengan aktor non-negara dalam mencapai target Sustainable Development Goals (SDGs) khususnya dalam hal ini upaya untuk mengakhiri perkawinan anak di Indonesia. Hal ini sesuai dengan konsep kerjasama dalam menciptakan keamanan manusia yang harus diatasi oleh semua pemangku kebijakan dan pihak terkait baik dalam upaya penyelesaian, rehabilitasi dan pembangunan. Penelitian ini, oleh sebab itu, berbeda dengan penelitian-penelitian terkait sebelumnya yang banyak disitasi dari Hanmer \& Elefante (2016)dan Grijns, M. and Horii (2018).

Laporan World Bank yang ditulis oleh Hanmer \& Elefante (2016) menganalisa isu perkawinan anak secara umum dan bagaimana fenomena tersebut terjadi hampir di seluruh dunia sehingga seakan menjadi fenomena global. Laporan tersebut berfokus pada bagaimana perkawinan anak tidak lain adalah tindakan pelanggaran terhadap hak asasi manusia. Namun hasil laporan tersebut lebih banyak membahas mengenai fungsi dari akta lahir, reformasi dan desain kebijakan dalam persoalan perkawinan anak di berbagai negara termasuk Indonesia. Meski demikian, laporan ini bisa menjadi salah satu sumber data bagi tulisan ini dalam menjelaskan bagaimana dukungan dari World Bank sebagai donatur global terhadap persoalan perkawinan anak. Selain itu, laporan ini menekankan upaya global oleh 193 negara termasuk Indonesia dalam mengakhiri perkawinan anak yang telah disepakati sebagai target SDGs yang ke-5 yakni mencapai kesetaraan gender dan memberdayakan perempuan dewasa dan anak perempuan. Lebih spesifik, target SDGs ke-5 yang disepakati tersebut teruraikan dalam poin 5.3 yakni saling bekerjasama untuk melenyapkan seluruh praktik buruk terhadap anak, pernikahan dini dan dipaksakan serta khitan perempuan pada tahun 2030 (Girls Not Brides, 2021b). Perkawinan anak menurut Hanmer \& Elefante (2016, p. 1) seharusnya dapat dihentikan karena memiliki banyak dampak buruk terhadap anak yang mengalaminya.

Penelitian yang paling banyak dikutip adalah penelitian oleh Rumble et al.(2018). Dalam penelitian ini Rumble et al. (2018) menyatakan bahwa persoalan 
terkait perkawinan anak merupakan persoalan yang krusial di negara miskin dan berkembang. Meski demikian Rumble et al.(2018) juga menemukan bahwa studi terkait kasus di negara-negara Asia Tenggara belum sebanyak Afrika dan Asia Selatan. Penelitian dari Rumble et al.(2018) sendiri menggunakan model kuantitatif guna menemukan faktor determinan dari perkawinan anak di Indonesia. Tingkat pendidikan, kekayaan dan eksposur media menjadi tiga determinan utama yang mempengaruhi perkawinan anak. Selain itu Rumble et al.(2018) juga berargumen bahwa perkawinan anak bukanlah mengatasi kemiskinan sebagaimana tujuan yang diharapkan namun malah melanggengkannya. Untuk itu perlu adanya perubahan terhadap Undang-Undang Perkawinan. Penelitian ini pada akhirnya terjawab dengan adanya perubahan terhadap UU Perkawinan yang lama UU No. 11974 menjadi UU No. 16 Tahun 2019 (Yasin, 2019).

Selain terkait perkawinan anak, penelitian yang juga secara khusus membahas tentang peran lembaga asing atau kerjasama dengan mereka menjadi penting untuk ditelusuri. Hal ini guna memberi gambaran mengenai bagaimana dan seperti apa kerjasama atau dukungan asing terhadap upaya pencapaian SGDs yang khusus berfokus kepada perkawinan anak. Ini menjadi krusial karena selama ini pernikahan anak menjadi agenda yang senantiasa menjadi perdebatan oleh mereka yang pro dan kontra. Kritik terhadap asing cukup besar terutama dari masyarakat dan lembaga pendidikan Islam karena dianggap sebagai upaya liberalisasi norma dan tradisi agama dan keIndonesiaan. Padahal persoalan mengenai keberadaan asing dalam konteks persoalan pembangunan seperti perkawinan anak harusnya menjadi bahan belajar untuk seluruh pihak dan upaya mencari jalan keluar bersama.

Lebih lanjut, penelitian terkait kerjasama asing dan pemerintah Indonesia pernah dilakukan oleh Putri dan Utomo (2019) sebelumnya. Namun, penelitian tersebut berfokus pada isu perdagangan dan perbudakan manusia. Dalam penelitiannya, Putri dan Utomo (2019) mengangkat soal kemitraan IOM dengan Pemerintah Indonesia. Kerjasama tersebut dilakukan dengan berbagai cara yakni meningkatkan kesadaran masyarakat, melakukan observasi terhadap mekanisme tenaga kerja, melakukan advokasi terhadap korban kejahatan manusia dan memperkuat sistem di Indonesia baik melalui peningkatan kapasitas sumber daya 
manusia dan institusi serta hukum dan peradilan. Bahkan IOM juga bekerjasama dengan pemerintah Indonesia dalam membangun Gugus Tugas pemberantasan perdagangan manusia.

Sedangkan berdasarkan kajian dari Annisa R. Beta dan Febrianto (2020) yang menggunakan pendekatan kritis dalam memahami perkawinan anak dengan melihat kembali bagaimana persepsi mengenai bagaimana idealnya anak tumbuh menjadi tidak sesuai dengan realitas yang terjadi di negara miskin dan berkembang (Global South) seperti Indonesia yang tidak memiliki banyak opsi sebagaimana anak-anak di negara maju (Global North).

Penelitian terbaru dilakukan oleh Lubis et al. (2021) yang berfokus kepada strategi Lembaga Swadaya Masyarakat dalam mengatasi kasus perkawinan anak dan bagaimana LSM tersebut bekerjasama dengan LSM dan organisasi asing seperti LBH APIK dan OXFAM. Lubis et al. (2021) menemukan bahwa upaya LSM dan organisasi tersebut didasari oleh tujuan demi menciptakan keamanan manusia. Selain itu, tulisan dari Aninda (2021) juga memberikan uraian terkait perkawinan anak di masa pandemi Covid 19 yang terjadi menurutnya sebab minimnya aktivitas anak dan kurangnya pengawasan orangtua yang pada akhirnya menyebabkan pergaulan bebas dan juga kasus hamil di luar nikah.

\section{METODE PENELITIAN}

Metode penelitian yang digunakan dalam penelitian ini adalah penelitian analisis kualitatif dengan menggunakan metode studi pustaka. Metode ini bertujuan menggunakan data yang bersumber dari sumber kedua yang bisa berupa hasil penelitian, dokumen resmi, website, hasil wawancara sebelumnya, press release dan sebagainya(Snyder, 2019). Data tersebut kemudian dianalisis dengan cara, pertama melakukan telaah data dari berbagi dokumen resmi yang dikeluarkan oleh pemerintah Indonesia, lembaga asing dan lembaga masyarakat yang terkait dengan pernikahan anak. Setelah mengumpulkan dan menelaah data tersebut kemudian melakukan reduksi data, yakni memisahkan data yang dianggap paling relevan dan kurang relevan bahkan tidak relevan dengan pertanyaan penelitian. Setelah itu data disusun dan dikategorisasi kemudian 
ditafsirkan(Kothari, 2004).

\section{HASIL DAN DISKUSI}

Hasil data dari tiga sumber utama yakni dokumen pemerintah Indonesia, laporan LSM lokal dan internasional serta dari berita menunjukkan bahwa kolaborasi dan kerjasama telah dan terus dilakukan terutama dalam mencegah peningkatan dan potensi kenaikan jumlah perkawinan anak di dunia akibat Pandemi Covid 19 sebagaimana yang disebut oleh UNICEF bahwa akan terjadi 10 juta perkawinan anak di dunia akibat Covid 19(Bappenas, 2020b).

Gentingnya persoalan mengenai perkawinan anak bukan hanya menjadi perhatian pemerintah Indonesia. Sebagai bagian dari masyarakat dunia, Indonesia telah menjadi bagian dari gerakan global untuk mengakhiri perkawinan anak yang dianggap telah melanggar hukum internasional dan Hak Anak (UNICEF Indonesia, 2020, p. 8). Baik dalam kedudukannya sebagai anggota PBB maupun kerjasama bilateral atau regional dengan berbagai pihak (negara dan non-negara). Dalam keikutsertaanya untuk berkomitmen terhadap pencapaian SDGs, Indonesia melalui Kementerian Pemberdayaan Perempuan dan Anak, Kementerian Agama, Kementerian Pendidikan dan Kebudayaan,Kementerian Koordinator Bidang Pembangunan Manusia dan Kebudayaan telah bekerjasama dalam berbagai program(Bappenas, 2020b).

Perkawinan anak menjadi salah satu isu krusial dalam target pembangunan sebab perkawinan anak sangat terkait terhadap konsep keamanan manusia. Konsep keamanan manusia berbeda dengan konsep keamanan tradisional yang berfokus kepada konteks keamanan dari ancaman militer dan kedaulatan negara. Konsep keamanan manusia berfokus kepada terbebasnya individu oleh ancaman baik dalam bentuk kekerasan dan non-kekerasan seperti kemiskinan, kelaparan, polusi, hingga pelanggaran HAM (Prasetyono et al., n.d., p. 8). Keamanan manusia dalam hal ini tidak bisa dipandang sebagai ancaman yang dihadapi oleh satu negara saja, namun merupakan persoalan global karena data menunjukkan bahwa kasusnya sendiri hampir terjadi di semua negara di dunia. UNICEF mencatat bahwa setiap tahun angka perkawinan anak bertambah jutaan di seluruh dunia (UNICEF, 
2021a, p. 6).

Menyadari bahwa perkawinan anak adalah persoalan global, maka untuk mengatasinya membutuhkan prinsip solidaritas global dibandingkan sebagai kepentingan kolektif semata. Dengan menggunakan prinsip solidaritas global, pencegahan dan penghentian pernikahan anak akan mampu dilakukan dengan kolaboratif dan komprehensif. Peran negara melalui kementerian dan lembaga lainnya hingga ke tingkat desa menjadi penting dalam konteks tersebut, namun persoalan dengan negara berkembangan seperti Indonesia terletak lebih dominan pada rendahnya kompetensi Sumber Daya Manusia dan juga pendanaan (Yayasan Plan International Indonesia, 2021b). Oleh sebab itu, kolaborasi internasional sangat dibutuhkan dalam dua hal tersebut.

Kemitraan global telah menjadi salah satu aspek yang gencar dilakukan oleh negara-negara untuk bisa bersama-sama mengatasi persoalan perkawinan anak. Hal ini sebagai implikasi dari globalisasi yang bukan hanya menyebabkan masalah satu negara bisa membawa implikasi bagi negara lain tetapi juga nilai kosmopolitanisme mengenai penegakan HAM sebagai nilai-nilai dasar sebuah negara atau entitas internasional menjadi kepentingannya juga semisal bagaimana Uni Eropa menjadikan keadilan gender antara laki-laki dan perempuan sebagai nilai fundamentalnya sesuai yang tertera dalam Traktat Roma 1957(European Comission, 2020, p. 1).

Selain Uni Eropa, PBB sebagai organisasi internasional memiliki agenda utama yakni menciptakan perdamaian dunia. Dalam tujuannya itu, maka PBB menggunakan perspektif keamanan manusia dalam menciptakan perdamaian tersebut melalui tindakan bersama dalam berbagai momentum(United Nations Trust Fund, 2016, p. 5). Hal ini selaras dengan pendekatan sistem yang dipakai dalam PBB berdasarkan General Assembly resolution 66/290 pada tanggal 10 September 2012(United Nations Trust Fund, 2016, p. 6). Dimana semua negara di bawah PBB menyepakati untuk menggunakan keamanan manusia dalam seluruh kebijakannya dan termasuk kerjasamanya. Paling tidak momentum kerjasama tersebut tergambarkan dari kesepakatan Millenium Development Goals pada tahun 2000 dan Sustainable Development Goals pada 2015(Girls Not Brides, 2021b). Selain itu itu berbagai upaya tindaklanjut dilakukan yang terimplementasi di 
berbagai program kemitraan baik dalam kerangka regional maupun internasional. Beberapa organisasi di bawah PBB seperti United Nation Population Fund (UNPF) dan United Nations Children's Fund (UNICEF) telah bekerja di Indonesia bahkan sebelum Perang Dingin berakhir dalam mendorong kesetaraan gender termasuk di dalamnya upaya melindungi perempuan. Pemerintah sendiri telah bekerjasama dengan UNFPA sejak tahun 1971. Kerjasama tersebut telah melalui beberapa siklus kerjasama. Kerjasama terakhir adalah Siklus 10 yang sedang berjalan dan akan berakhir pada 2025(Bappenas, 2021, p. 1).

Di sisi lain, UNICEF yang didukung oleh beberapa negara Eropa(Savitri, 2016) telah melakukan berbagai upaya yang sama dengan melibatkan berbagai pihak di Indonesia selama 70 tahun. Sebagaimana yang ditulis pada halaman websitenya, UNICEF telah menghasilkan penelitian, menyusun kertas kebijakan dan program, dan memberikan dukungan praktis agar layanan penting dapat direncanakan, didanai, dan diberikan secara dan berfokus kepada mereka yang paling rentan(UNICEF, 2021b). UNICEF juga banyak bekerja dengan pemerintah secara langsung seperti perubahan kebijakan, upaya advokasi di lapangan hingga temuan dan penelitian. Hal ini tercermin dalam laporan oleh Bappenas (2020a, 2020b) dan yang dikeluarkan oleh UNICEF Indonesia (2020) sendiri bekerja dengan Kementerian Koordinator Bidang Pembangunan Manusia dan Kebudayaan; Kementerian Pemberdayaan Perempuan dan Perlindungan Anak (KPPPA); Kependudukan dan Keluarga Nasional Badan Perencanaan (BKKBN); Kementerian Pendidikan dan Kebudayaan; Kementerian Kesehatan; Kementerian Dalam Negeri; Kementerian Agama; Kementerian Sosial; Kementerian Komunikasi dan Informatika; Kementerian Desa, Pembangunan Daerah Tertinggal, dan Transmigrasi; Komisi Nasional tentang Kekerasan terhadap Perempuan (Komnas Perempuan); Komisi Perlindungan Anak Nasional (KPAI) bekerja sama.

Selain PBB dan Eropa, Indonesia juga memperoleh dukungan dari berbagai pihak asing semisal Australia yang juga sangat fokus kepada isu perempuan dalam pembangunan. Sebuah penelitian juga telah dilakukan antara University of Melbourne dan The Australia-Indonesia Partnership for Gender Equality and Women's Empowerment (Melbourne Institute University of Melbourne, 2021). 


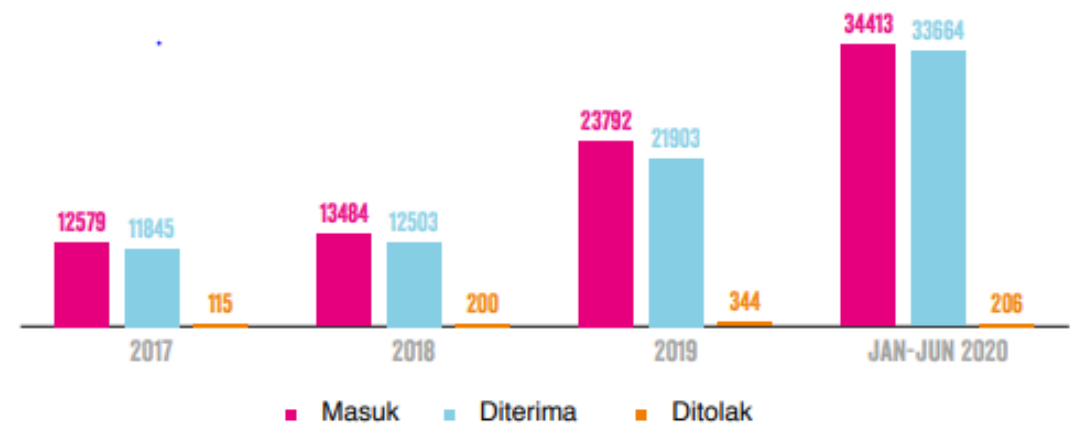

Sumber: Yayasan Plan International Indonesia (2021,p. 23)

Progress yang dicapai oleh Indonesia melalui Strategi Nasional Pencegahan Perkawinan Anak (STRANAS PPA) selain sebagai bagian dari Rencana Pembangunan Jangka Menengah (RPJMN) dan perdes juga atas kolaborasi bersama dengan aktor internasional (Yayasan Plan International Indonesia, 2021b, p. 11). STRANAS sendiri dihasilkan dengan bantuan dari UNFPA, UNICEF, DFAT, and the Government of Canada(Kementerian Pemberdayaan Perempuan dan Perlindungan Anak RI, 2020).

Selain itu, Indonesia juga berkolaborasi dengan Girls Not Brides. Girls Not Brides (2021a) merupakan jejaring global yang menangungi lebih dari 1.500 lembaga masyarakat dari 100 negara untuk membangun strategi guna mengakhiri perkawinan anak. Untuk Indonesia sendiri, ada enam organisasi yang ikut dalam jejaring tersebut (Sinaga, 2018) termasuk di dalamnya yakni Plan Indonesia. Palan Indonesia di bawah Kemitraan Girls Not Bride paling tidak pada tahun 2016, melakukan penandatanganan bersama dengan 13 organisasi kemasyarakatan (Kementerian Pemberdayaan Perempuan Dan Perlindungan Anak, 2016). Selain itu Plan Indonesia memiliki dan mendukung berbagai program yang dilakukan dalam mengakhiri perkawinan anak bahkan sejak 1969(Yayasan Plan International Indonesia, 2021a). Salah satunya dengan mendukung program inisiatif di Kebumen yakni adanya radio yang dijalankan oleh anak muda lokal dengan melakukan kampanye anti perkawinan anak, meningkatkan kesadaran masyarakat lokal mengenai dampak buruk dari praktik tersebut. Plan Indonesia juga bekerjasama dengan komunitas-komunitas lokal seperti Aliansi Remaja Independen di Lombok (Girls Not Brides, 2018). 
Meski demikian tentu saja upaya mengatasi perkawinan anak bukan hanya soal pendanaan dan dukungan SDM yang berkualitas namun juga political will dari pengambil kebijakan untuk tidak sekedar mendorong kolaborasi internasional dan berharap kepada donor, aktor atau bantuan asing tetapi juga melakukan reformasi kebijakan dan mengikutsertakan berbagai pihak yang memiliki peran kunci seperti pesantren dan lembaga pendidikan. Hal ini agar hubungan kolaboratif bersifat adil dan tidak menimbulkan benturan kepentingan. Argumentasi tersebut didasarkan pada analisis penulis mengenai upaya dan strategi yang sangat banyak yang telah dilakukan selama ini sebagaiman dijelaskan pada bagian sebelumnya. Namun pada tahapan implementasi, hal tersebut tidak aplikatif. Misalnya dalam temuan oleh Yayasan Plan International Indonesia (2021, pp. 11-14) diperoleh bahwa meskipun UU pernikahan telah diubah namun dispensasi nikah masih diberikan oleh banyak hakim sehingga perkawinan anak masih terus terjadi. Hal ini sebabkan masih rendahnya pemahaman atau interpretasi bersama terkait dengan UU Pernikahan yang baru. Dalam konteks itu, lembaga asing juga masing melakukan pendampingan dan dukungan berupa kertas kebijakan untuk mendorong adanya upaya yang lebih efektif dan berkelanjutan.

\section{KESIMPULAN}

Perkawinan anak di Indonesia merupakan salah satu masalah sosial yang cukup mengkhawatirkan. Hal ini diperparah dengan adanya Pandemi Covid-19 yang telah menyebabkan kemiskinan dan kesenjangan sosial yang juga makin tinggi hingga mendorong kenaikan perkawinan anak. Meski demikian, kolaborasi dan kerjasama antara pihak Indonesia baik pada level pengambil kebijakan maupun masyarakat menjadi poin penting dalam upaya mengatasi perkawinan anak terutama di masa Pandemi Covid 19. Hal ini sebab tantangan dalam mengatasi perkawinan anak tidak mudah, dibutuhkan dukungan kebijakan, finansial dan upaya-upaya bersama yang tidak hanya menjadi tanggung jawab salah satu pihak. Penelitian ini sendiri menemukan bahwa aktor asing sangat berperan besar dalam bukan hanya mengatasi masalah perkawinan anak tapi juga dalam mencegahnya baik melalui pemberian bantuan teknis, pelatihan dan upaya advokasi berupa kerjasama 
lembaga internasional dan universitas serta lembaga pendidikan keagaamaan dan dukungan terhadap organisasi kemasyarakatan. Hal ini didasarkan oleh adanya nilai-nilai dasar mengenai HAM yang menjadi nilai-nilai yang diperjuangkan oleh aktor-aktor internasional tersebut.

\section{DAFTAR PUSTAKA}

Aninda, E. (2021). Meningkatnya Angka Perkawinan Anak Saat Pandemi Covid-19. INFO Singkat, 13(4), 13-18. https://scholar.google.com/scholar?hl=en\&as_sdt=0\%2C5\&q=MENINGKATN $\mathrm{YA}+\mathrm{ANGKA}+\mathrm{PERKAWINAN+ANAK+SAAT+PANDEMI+COVID-19 \& btnG=}$

Annisa R. Beta dan Febrianto, R. (2020). Are Indonesian Girls Okay? An Examination of The Discourse of Child Marriage, Victimization, And Humanitarian Visuality Of Global South Girls. Jurnal Studi Pemuda, 9(2). https://journal.ugm.ac.id/jurnalpemuda/article/view/57432

Bappenas. (2020a). National Strategy on Child Marriage Prevention 2020. In unicef.org.

https://www.unicef.org/indonesia/sites/unicef.org.indonesia/files/2020-

06/National-Strategy-on-Child-Marriage-Prevention-2020.pdf

Bappenas. (2020b). Pencegahan Perkawinan Anak.

Bappenas. (2020c). PERKEMBANGAN EKONOMI INDONESIA DAN DUNIA Ancaman... Google

Scholar.

https://scholar.google.com/scholar?hl=en\&as_sdt=0\%2C5\&q=PERKEMBANG AN+EKONOMI+INDONESIA+DAN+DUNIA+Ancaman+Resesi+Dunia+Akibat+P andemi\&btnG $=$

Bappenas. (2021). pedoman umum pelaksanaan program kerjasama pemerintah RI dan UNFPA.

BBC Indonesia. (2021). Dampak Covid-19: 2,7 juta orang masuk kategori miskin selama pandemi, pemulihan ekonomi "butuh waktu lama." https://www.bbc.com/indonesia/indonesia-55992498

Connor, P. (2020). 91\% of world population lives in countries with restricted travel 
amid COVID-19 / Pew Research Center. https://www.pewresearch.org/facttank/2020/04/01/more-than-nine-in-ten-people-worldwide-live-incountries-with-travel-restrictions-amid-covid-19/

Detikcom. (2021). Apa Itu Lockdown: Pengertian dan Dampaknya. https://www.detik.com/edu/detikpedia/d-5506057/apa-itu-lockdownpengertian-dan-dampaknya

European Comission. (2020). Spotlight On EU Action for Women.

Girls Not Brides. (2018). In Indonesia, youth activists are demanding change for girls. https://www.girlsnotbrides.org/articles/in-indonesia-youth-activists-aredemanding-an-end-to-child-marriage/

Girls Not Brides. (2021a). About us. https://www.girlsnotbrides.org/about-us/ Girls Not Brides. (2021b). Child marriage and the SDGs. https://www.girlsnotbrides.org/learning-resources/child-marriage-andsdgs/

Grijns, M. and Horii, H. (2018). Child marriage in a village in West Java (Indonesia): Compromises between legal obligations and religious concerns. Asian Journal of Law and Society 5, 2, 453-466. https://www.cambridge.org/core/journals/asian-journal-of-law-andsociety/article/child-marriage-in-a-village-in-west-java-indonesiacompromises-between-legal-obligations-and-religiousconcerns/19FFFDCEE4C5817B7A2083254D99FE20

Hanmer, L., \& Elefante, M. (2016). The role of identification in ending child marriage. https://openknowledge.worldbank.org/handle/10986/25184

Katadata. (2021). Wabah Pernikahan Dini di Tengah Pandemi dan Dampak Buruknya - $\quad$ Analisis Data Katadata. https://katadata.co.id/muhammadridhoi/analisisdata/5ff7cb5cdf279/wabah -pernikahan-dini-di-tengah-pandemi-dan-dampak-buruknya

KEMENTERIAN PEMBERDAYAAN PEREMPUAN DAN PERLINDUNGAN ANAK. (2016). Kampanye Girls Not Bride. https://www.kemenpppa.go.id/index.php/page/read/30/289/kampanyegirls-not-brides-didukung

Kementerian Pemberdayaan Perempuan dan Perlindungan Anak RI. (2020). 
Strategi Nasional Pencegahan Pernikahan Anak.

Kompas. (2021). PDB Per Kapita Merosot akibat Pandemi Covid-19 - Kompas.id. https://www.kompas.id/baca/ekonomi/2021/02/08/bank-dunia-covid-19menghapus-pendapatan-per-kapita-dalam-10-tahun

Kothari, C. R. (2004). Research methodology: Methods and techniques. New Age International.

Lubis, A., Baharuddin, A., ... A. M.-G. J. of, \& 2021, U. (2021). NGOs and Child Marriage Problem in Indonesia: Analysis of Issues, Strategies and Networks. Jurnal.Unigo.Ac.Id. https://jurnal.unigo.ac.id/index.php/gjgops/article/view/1346

Mary A. Shiraef. (2021, March 19). Closed borders, travel bans and halted immigration: 5 ways COVID-19 changed how - and where - people move around the world. https://theconversation.com/closed-borders-travel-bansand-halted-immigration-5-ways-covid-19-changed-how-and-where-peoplemove-around-the-world-157040

Melbourne Institute University of Melbourne. (2021). Child Marriage in Indonesia. Mutia, A. (2021, August 31). BPS: Tingkat Pengangguran Anak Muda Semakin Tinggi Saat Pandemi / Databoks. https://databoks.katadata.co.id/datapublish/2021/08/31/bps-tingkatpengangguran-anak-muda-semakin-tinggi-saat-pandemi

Prasetyono, E., Muna, R., \& Syaltout, M. (n.d.). Kaji Ulang Indeks Keamanan Manusia Indonesia 2013. Ditpolkom.Bappenas.Go.Id. Retrieved November 4, 2021, from http://ditpolkom.bappenas.go.id/basedir/Kajian Ditpolkom/3) Kajian Tahun 2014/Indeks Keamanan/Indeks Keamanan.pdf

Putri, D. A. A. dan T. C. U. (2019). Kerjasama International Organization for Migration (IOM) dan Pemerintah Indonesia dalam Menangani Perdagangan dan Perbudakan Manusia di Industri. Journal of International Relations, 5(1), 998-1006.

https://ejournal3.undip.ac.id/index.php/jihi/article/download/22708/2076 9

Rumble, L., Peterman, A., Irdiana, N., Triyana, M., \& Minnick, E. (2018). An empirical exploration of female child marriage determinants in Indonesia. BMC Public 
Health, 18(1). https://doi.org/10.1186/S12889-018-5313-0

Save The Children. (2021). Child marriage kills more than 60 girls a day / Save the Children International. https://www.savethechildren.net/news/childmarriage-kills-more-60-girls-day

Savitri, A. W. (2016). UNICEF Luncurkan Program Cegah Perempuan Menikah di Bawah Umur.

SINAGA, D. A. (2018). Girls Not Brides Joins Hands With Local NGOs to End Child Marriage in Indonesia. https://jakartaglobe.id/news/girls-not-brides-joinshands-local-ngos-end-child-marriage-indonesia/

Snyder, H. (2019). Literature review as a research methodology: An overview and guidelines. Journal of Business Research, 104, 333-339. https://doi.org/10.1016/j.jbusres.2019.07.039

UNICEF. (2021a). A threat to progress against child marriage. file://C:/Users/USER/Downloads/UNICEF-report-_-COVID-19-_-A-threat-toprogress-against-child-marriage-1.pdf

UNICEF. (2021b). Upaya UNICEF. https://www.unicef.org/indonesia/id/what-wedo

UNICEF Indonesia. (2020). Situasi Anak di Indonesia - Tren, Peluang, dan Tantangan Dalam Memenuhi Hak-Hak Anak.

United Nations Trust Fund. (2016). Human Security Handbook.

WHO. (2021). WHO Coronavirus (COVID-19) Dashboard / WHO Coronavirus (COVID19) Dashboard With Vaccination Data. The Conversation. https://covid19.who.int/

Yasin, M. (2019). Dispensasi Perkawinan Tetap Dimungkinkan, Begini Syaratnya Menurut PU Perkawinan yang Baru. (Https://Www.Hukumonline.Com/Berita/Baca/Lt5Db127B0B52F3/Dispens asi-Perkawinan-Tetap-Dimungkinkan--Begini-Syaratnya-Menurut-UuPerkawinan-Yang-Baru.

https://www.hukumonline.com/berita/baca/lt5db127b0b52f3/dispensasiperkawinan-tetap dimungkinkan--begini-syaratnya-menurut-uu-perkawinanyang-baru/

Yayasan Plan International Indonesia. (2021a). Tentang Kami - Yayasan Plan 
International Indonesia. https://plan-international.or.id/id/tentang-plan/ Yayasan Plan International Indonesia, K. P. I. U. K. dan D. (2021b). Perkawinan Bukan Untuk Anak: Potret Perkawinan Anak di 7 Daerah Paska Perubahan UU Perkawinan. 